\title{
Perencanaan Pajak dan Beban Pajak Tangguhan terhadap Manajemen Laba Pada Perusahaan Manufaktur yang Terdaftar di Bursa Efek Indonesia
}

\author{
Lusiana Kanji ${ }^{1)}$ \\ Email: lusiana.kanji@stiem-bongaya.ac.id \\ ${ }^{1}$ Dosen Akuntansi, STIEM Bongaya Makassar \\ (Diterima: 15 Januari 2019; di revisi: 25 Februari-2019; dipublikasikan: 10 April-2019)
}

(C2019 -Bongaya Journal for Research Accounting STIEM Bongaya. Ini adalah artikel dengan akses terbuka dibawah licenci CC BY-NC-4.0 (https://creativecommons.org/licenses/by-nc/4.0/).

\begin{abstract}
ABSTRAK
Penelitian ini bertujuan untuk menguji pengaruh perencanaan pajak dan beban pajak tangguhan terhadap manajemen laba. Objek penelitian ini yaitu perusahaan-perusahaan manufaktur yang terdaftar di Bursa Efek Indonesia (BEI) dengan periode pengamatan tahun 2013 sampai tahun 2015. Data yang digunakan dalam penelitian ini yaitu data berdasarkan laporan keuangan tahunan yang diperoleh dari Galeri Investasi STIEM Bongaya Makassar. Metode pengambilan sampel dengan menggunakan purposive sampling dan metode analisis data menggunakan analisis regresi berganda. Hasil penelitian ini menunjukkan bahwa perencanaan pajak dan pajak tangguhan tidak memiliki pengaruh signifikan terhadap manajemen laba.
\end{abstract}

Kata Kunci : Perencanaan Pajak, Beban Pajak Tangguhan, Manajemen Laba

\section{PENDAHULUAN}

Laba merupakan ukuran paling sederhana untuk menilai kinerja perusahaan. Informasi tentang laba (earnings) mempunyai peran sangat penting bagi pihak yang berkepentingan terhadap suatu perusahaan. Dalam menganalisis laporan keuangan baik pihak internal maupun eksternal, laba sering digunakan sebagai dasar untuk pembuatan keputusan seperti pemberian kompensasi dan pembagian bonus kepada manajer, ukuran prestasi atau kinerja manajemen dan dasar penentuan besarnya pengenaan pajak.

Oleh karena itu, kualitas laba menjadi pusat perhatian bagi investor, kreditor, pembuat kebijakan akuntansi, dan pemerintah dalam hal ini adalah Direktorat Jendral Pajak.

Tujuan yang ingin dicapai manajemen adalah mendapatkan laba yang tinggi. Hal ini berkaitan dengan bonus yang akan diperoleh oleh manajemen, karena semakin tinggi laba yang diperoleh, maka akan semakin tinggi pula bonus yang akan diberikan oleh perusahaan kepada pihak manajemen sebagai pengelola secara langsung.

Informasi laba dapat membantu pemilik (stakeholders) dalam mengestimasi earnings power (kekuatan laba) untuk menaksir resiko dalam investasi dan kredit. Pentingnya informasi laba tersebut merupakan tanggung jawab dari pihak manajemen yang diukur kinerjanya dari pencapaian laba yang diperoleh. 
Perusahaan dihadapkan dengan persaingan yang keras untuk dapat eksis dalam pasar global, khususnya untuk industri manufaktur di Indonesia. Dalam rangka untuk kuat bersaing, perusahaan dituntut untuk memiliki keunggulan kompetitif dari perusahaan lainnya.

Perusahaan tidak hanya dituntut untuk menghasilkan produk yang bermutu bagi konsumen, tetapi juga mampu mengelola keuangannya dengan baik, artinya kebijakan pengelolaan keuangan harus dapat menjamin keberlangsungan usaha perusahaan dan hal tersebut ditunjukkan dengan besarnya laba yang dicapai suatu perusahaan. Situasi inilah yang biasanya mendorong manajer untuk melakukan perilaku menyimpang dalam menyajikan dan melaporkan informasi laba tersebut yang dikenal dengan praktik manajemen laba (earnings management).

Tindakan manajemen memanipulasi laporan keuangan dengan menaikkan laba mengindikasikan adanya praktik manajemen laba pada perusahaan. Manajemen laba merupakan upaya yang dilakukan pihak manajemen untuk melakukan intervensi dalam penyusunan laporan keuangan dengan tujuan untuk menguntungkan dirinya sendiri, yaitu pihak perusahaan yang terkait.

Manajemen laba dapat dilakukan dengan pemerataan laba (income smoothing), taking a bath, dan income maximization. Konsep mengenai manajemen laba dapat dijelaskan dengan menggunakan pendekatan teori keagenan (agency theory).
Teori tersebut menyatakan bahwa praktik manajemen laba dipengaruhi oleh konflik kepentingan antara pihak yang berkepentingan (principal) dengan manajemen sebagai pihak yang menjalankan kepentingan (agent).

Perusahaan untuk merekayasa informasi melalui praktik manajemen laba telah menjadi faktor utama yang menyebabkan laporan keuangan tidak lagi mencerminkan nilai fundamental suatu perusahaan. Oleh karena itu, perekayasaan laporan keuangan telah menjadi isu sentral sebagai sumber penyalahgunaan informasi yang dapat merugikan pihak-pihak yang berkepentingan. Itulah sebabnya informasi yang disampaikan terkadang diterima tidak sesuai dengan kondisi perusahaan yang sebenarnya. Kondisi ini dikenal sebagai asimetri informasi (information asymetric) yakni kondisi dimana ada ketidakseimbangan perolehan informasi antara pihak manajemen sebagai penyedia informasi dengan pemegang saham dan stakeholders (Hairu, 2009:1).

Keinginan pihak manajemen untuk menekan dan membuat beban pajak sekecil mungkin, maka pihak manajemen cenderung untuk meminimalkan pembayaran pajak. Upaya untuk meminimalkan beban pajak sering disebut dengan perencanaan pajak (tax planning) atau tax sheltering (Suandy, 2011). Umumnya perencanaan pajak merujuk kepada proses merakayasa usaha dan transaksi wajib pajak supaya utang pajak berada dalam jumlah yang minimal tetapi masih dalam bingkai peraturan perpajakan yang berlaku, sehingga perencanan 
pajak (tax planning) merupakan tindakan yang legal selama dalam koridor undang-undang perpajakan yang berlaku di Indonesia.

Manajemen PT Bursa Efek Indonesia (BEI) mencatat ada 63 perusahaan tercatat atau emiten belum menyampaikan laporan tahunan (annual report) tahun 2015 secara tepat waktu hingga 2 Mei 2016. Karena itu, bursa akan memberikan peringatan tertulis kepada 63 perusahaan tercatat yang tidak memenuhi kewajiban penyampaian laporan tahunan 2015 secara tepat waktu. Hal itu mengacu pada ketentuan II.1 Peraturan Nomor I-H tentang sanksi.

Adapun 63 perusahaan yang belum menyampaikan laporan tahunan 2015 secara tepat waktu itu antara lain 5 perusahaan tercatat menyampaikan keterbukaan informasi terlambat menyampaikan laporan tahunan 2015 dan 58 perusahaan tercatat tidak menyampaikan informasi penyebab keterlambatan penyampaian laporan tahunan. Mengutip keterangan tertulis BEI, Kamis (16/6/2016), selain itu BEI mencatat dari 581 perusahaan tercatat, sekitar 487 perusahaan tercatat telah menyampaikan laporan tahunan tahun 2015. (Liputan6.com).

Pajak merupakan salah satu sumber penerimaan negara, termasuk Indonesia yang mengandalkan penerimaan pajak sebagai sumber penerimaan negara yang utama (Haula Rosdiana, Edi Slamet Irianto, 2010). Salah satu sektor pajak yang paling besar diperoleh Negara adalah pajak penghasilan. Untuk akuntansi pajak penghasilan, setiap perusahaan di Indonesia dalam membuat laporan keuangan diharuskan untuk mengikuti kaidah Pernyataan Standar
Akuntansi Keuangan (PSAK) agar dapat menghasilkan laporan keuangan yang kredibel dan informatif kepada investor dan kreditor.

Selain itu, perusahaan juga diharuskan untuk menyusun laporan laba rugi berdasarkan aturan perpajakan. Sejumlah perbedaan antara PSAK dan aturan pajak menghasilkan dua jenis penghasilan, yaitu laba sebelum pajak (perhitungan laba akuntansi menurut PSAK) dan penghasilan kena pajak (perhitungan laba fiskal menurut aturan fiskal).

Perbedaan antara laba akuntansi dan laba fiskal dapat menimbulkan kesulitan dalam penentuan besarnya laba, sehingga bisa mempengaruhi posisi laporan keuangan dan menyebabkan tidak seimbangnya saldo akhir. Oleh karena itu, perlu penyesuaian saldo antara laba akuntansi dengan laba fiskal melalui rekonsiliasi fiskal. Perbedaan temporer antara laba akuntansi dan laba fiskal menimbulkan beban pajak tangguhan.

Adanya perbedaan antara laba akuntansi dan penghasilan kena pajak menjadi salah satu instrumen bagi manajer untuk melakukan manajemen laba dan akan merefleksikan tingkat kebijakan manajer dalam memanipulasi laba menjadi lebih tinggi (Mills dalam Ettredge et al., 2008 dalam Deviana, 2010).

Hal ini juga sejalan dengan penelitian sebelumnya yakni Satyaningrum (2016) hasil penelitian menunjukkan bahwa beban pajak tangguhan dan perencanaan pajak berpengaruh signifikan terhadap manajemen laba, dan sebaliknya hasil penelitian Anggreni (2015) menunjukkan bahwa Tax management berpengaruh negatif terhadap kualitas laba dan 
kepemilikan manajerial memoderasi terhadap hubungan tax management dan kualitas laba.

Hasil penelitian Herdawati (2015) menunjukkan bahwa perencanaan pajak dan beban pajak tangguhan memiliki pengaruh positif dan tidak signifikan terhadap manajemen laba. Hasil penelitian Mustika, Esti (2016) menunjukkan bahwa aset pajak tangguhan, beban pajak tangguhan, perencanaan pajak, asimetri informasi dan leverage, hanya variabel leverage yang memiliki tingkat signifikasi $0,033<0,05$ berpengaruh terhadap earnings management. Hasil penelitian Chairul, Issan (2016) menunjukkan bahwa beban pajak tangguhan memiliki pengaruh negatif dan signifikan terhadap manajemen laba, dan kepemilikan institusional memiliki pengaruh negatif dan signifikan terhadap manajemen laba.

Hasil penelitian Timuriana

menunjukkan bahwa aset pajak tangguhan berpengaruh terhadap manajemen laba, beban pajak tangguhan tidak berpengaruh terhadap manajemen laba, dan aset pajak tangguhan dan beban pajak tangguhan secara bersama-sama berpengaruh terhadap manajemen laba.

Berdasarkan hasil penelitian yang tidak konsisten di antara kalangan peneliti terdahulu, dan berdasarkan pada fenomena yang terjadi dengan ditemukannya beberapa perusahaan yang terlambat menyampaikan laporan keuangannya yang telah diaudit dari tahun ke tahun yang meskipun mendapatkan sanksi atas keterlambatannya perusahaan tersebut tetap mengulang hal yang sama maka, penulis tertarik untuk mengambil judul "Pengaruh Perencanaan
Pajak dan Beban Pajak Tangguhan terhadap Manajemen Laba Pada Perusahaan Manufaktur yang Terdaftar di Bursa Efek Indonesia".

\section{TINJAUAN PUSTAKA}

\section{Teori Agency}

Agency Theory

Agency Theory menjelaskan hubungan antara agen (pihak manajemen suatu perusahaan) dengan principal (pemilik). Principal merupakan pihak yang memberikan amanat kepada agen untuk melakukan suatu jasa atas nama principal, sementara agent adalah pihak yang diberi mandat. Dengan demikian agent bertindak sebagai pihak yang berkewenangan mengambil keputusan, sedangkan principal ialah pihak yang mengevaluasi informasi.

Agency Theory merupakan teori yang membahas penentuan kontrak dalam pekerjaan yang paling efisien dan bisa mempengaruhi hubungan antara pemilik dan agent yang menjalankan. Teori keagenan memberikan kerangka pembelajaran mengenai kontrak yang terjadi antara principal dan agent sehingga bisa memprediksi konsekuensi ekonomi dari sebuah standar yang kemungkinan terjadi dalam kasus perusahaan (Godfrey et al., 2010:56)

Konsep manajemen laba dapat dimulai dari pendekatan teori agensi (agency theory). Hubungan keagenan merupakan sebuah kontrak antara manajemen (agent) dengan investor (principal). Pandangan agency theory yakni adanya pemisahan antara pihak principal dan agent yang menyebabkan munculnya potensi 
konflik yang dapat mempengaruhi kualitas laba yang dilaporkan. Maksud dengan principal dalam teori keagenan ini yakni pemegang saham atau pemilik yang menyediakan fasilitas dan dana untuk kebutuhan operasi perusahaan sedangkan agent adalah manajemen yang memiliki kewajiban mengelolah perusahaan sebagaimana yang telah diamanahkan principal kepadanya (Sanjaya, 2004 dan Sulistyanto, 2004 dalam Haryono, 2005).

Teori keagenan memiliki asumsi bahwa masing-masing individu semata-mata termotivasi oleh kesejahteraan dan kepentingan dirinya sendiri. Pihak principal termotivasi mengadakan kontrak untuk menyejahterakan dirinya melalui pembagian dividen atau kenaikan harga saham perusahaan. Sedangkan pihak agent termotivasi untuk meningkatkan kesejahteraannya melalui peningkatan kompensasi.

Konflik kepentingan semakin meningkat ketika principal tidak memiliki informasi yang cukup tentang kinerja agent karena ketidakmampuan principal memonitor aktivitas agent dalam perusahaan. Ditambah lagi agent mempunyai lebih banyak informasi mengenai kapasitas diri, lingkungan kerja, dan perusahaan secara keseluruhan. Hal inilah yang mengakibatkan adanya ketidakseimbangan informasi yang dimiliki oleh principal dan agent dan dikenal dengan istilah asimetri informasi. Asimetri informasi dan konflik kepentingan yang terjadi antara principal dan agent mendorong pihak agent untuk menyembunyikan beberapa informasi yang tidak diketahui oleh principal dan menyajikan informasi yang tidak sebenarnya kepada principal, terutama informasi tersebut berkaitan dengan pengukuran kinerja agent.

\section{METODE PENELITIAN}

Jenis, Sumber dan Teknik Pengumpulan Data

Jenis Data, Untuk keperluan penelitian ini digunakan data sekunder, yaitu data yang diperoleh dari pihak lain atau diperoleh tidak langsung dari sumber pertama dalam bentuk sudah jadi yang bersifat dokumenter. Data tersebut berupa laporan keuangan dari perusahaan manufaktur yang terdaftar di Galeri Investasi STIEM Bongaya Makassar selama tahun 2013 sampai tahun 2015.

Sumber Data, Penelitian ini menggunakan sumber data sekunder karena datadata diperoleh melalui dokumen laporan keuangan perusahaan. Dalam Sugiyono (2013:193), sumber sekunder merupakan sumber yang tidak langsung memberikan data kepada pengumpul data, misalnya lewat orang lain atau dokumen. Data yang didapat diambil dari Galeri Investasi STIEM Bongaya Makassar.

Dalam membuat penelitian ini, metode pengumpulan data yang digunakan adalah sebagai berikut:

1) Riset Kepustakaan (Library Research) yaitu riset dengan mengumpulkan bahan atau data-data yang ada kaitannya dengan objek pembahasan, yang diperoleh melalui penelitian kepustakaan, yaitu dengan mempelajari, meneliti, mengkaji, serta menelaah buku-buku, jurnal akuntansi. Riset kepustakaan juga mempelajari literaturliteratur serta membaca catatan perkuliahan yang berhubungan dengan permasalahan 
untuk mendapatkan teori, definisi, dan analisa yang dapat digunakan dalam penelitian ini.

2) Dokumentasi, Melakukan pengumpulan data dengan cara menggandakan data yang ada atau dengan cara membuat salinan.

\section{Populasi Penelitian}

Dalam penelitian ini yang menjadi populasi penelitian adalah seluruh perusahaan manufaktur yang menerbitkan laporan keuangan tahunan (annually report) yang diaudit dan dipublikasikan di Galeri Investasi STIEM Bongaya Makassar selama periode tahun 2013 sampai tahun 2015.

Proses pemilihan sampel dalam penelitian ini yaitu menggunakan metode purposive sampling. Metode purposive sampling adalah penentuan sampel berdasarkan kriteria yang telah dirumuskan terlebih dahulu oleh peneliti. Kriteria perusahaan yang dijadikan sampel data penelitian ini adalah sebagai berikut:

1) Perusahaan manufaktur sektor makanan dan minuman yang melaporkan laporan keuangan yang telah diaudit dari tahun 2013 sampai tahun 2015 dan mempublikasikan laporan keuangan untuk tahun yang berakhir dan Per 31 Desember.

2) Perusahaan tidak di-delisting selama periode pengamatan.

3) Perusahaan melaporkan beban pajak tangguhan pada tahun-tahun tertentu, yaitu antara tahun 2013-2015.

4) Perusahaan tidak melakukan akuisisi, merger, restrukturisasi, dan perubahan kelompok usaha. Adanya akuisisi, merger, restrukturisasi, serta perubahan kelompok usaha tersebut akan menyebabkan laporan keuangan disajikan berbeda sehingga mempengaruhi posisi dan kinerja keuangan perusahaan.

5) Perusahaan melaporkan laporan keuangan dalam satuan mata uang Rupiah (IDR).

\section{Metode Analisis}

Teknik analisis yang dipakai analisis regresi berganda Semua pengujian dilakukan dengan program komputer SPPS versi 23. Dengan persamaan sebagai berikut:

$$
\begin{array}{ll}
\mathrm{Y}=\mathrm{a}+\mathrm{b}_{1} \mathrm{X}_{1}+\mathrm{b}_{2} \mathrm{X}_{2}+€ \\
\mathrm{Y} & =\text { Manajemen Laba } \\
\mathrm{a} & =\text { Konstanta } \\
\mathrm{b}_{1}, \mathrm{~b}_{2}, & =\text { Koefisien Regresi } \\
\mathrm{X}_{1} & =\text { Perencanaan Pajak } \\
\mathrm{X}_{2} & =\text { Pajak Tangguhan } \\
€ & =\text { Batas Kesalahan }
\end{array}
$$

\section{HASIL DAN PEMBAHASAN}

\section{Hasil Uji Determinasi $\left(\mathbf{R}^{2}\right)$}

Nilai R untuk mengukur seberapa besar hubungan antara variabel dependen dan variabel independen. Sedangkan nilai $\mathrm{R}$ square $\left(\mathrm{R}^{2}\right)$ atau nilai koefisien determinasi pada intinya untuk mengukur sejauh mana kemampuan model menerangkan variasi variabel dependen. Hasil uji analisis koefisien determinasi dapat dilihat pada tabel 1 berikut : 
Tabel 1. Hasil Uji Koefisien Determinasi

\begin{tabular}{|c|c|c|c|c|}
\hline \multicolumn{5}{|c|}{ Model Summary } \\
\hline Model & R & R Square & $\begin{array}{l}\text { Adjusted R } \\
\text { Square }\end{array}$ & $\begin{array}{l}\text { Std. Error of the } \\
\text { Estimate }\end{array}$ \\
\hline 1 & $537^{\mathrm{s}}$ & 288 & .110 & 12.70732 \\
\hline \multicolumn{5}{|c|}{ a. Predictors: (Constant), Beban Pajak Jangguhan, Perencanaan Pajak } \\
\hline
\end{tabular}

Berdasarkan output tabel di atas diperoleh nilai koefisien determininasi $\mathrm{R}^{2}(\mathrm{R}$ square) yang diperoleh adalah 0,288 atau $28,80 \%$. Hal ini menunjukkan bahwa variasi variabel independen yang digunakan dalam model mampu menjelaskan sebesar 28,80\% manajemen laba dipengaruhi oleh perencanaan pajak dan pajak tangguhan, hal ini berarti bahwa sebesar 71,20\% manajemen laba dipengaruhi oleh faktor lain yang tidak diteliti dalam penelitian ini.

\section{Hasil Uji Parsial (Uji t)}

Pengujian hipotesis secara parsial dilakukan dengan uji t, pada dasarnya menunjukkan seberapa jauh pengaruh satu variabel penjelas secara individual dalam menerangkan variasi variabel terikat. Hasil uji parsial dalam penelitian ini dapat dilihat pada tabel 2 berikut:

\section{Tabel 2. Hasil Uji Parsial}

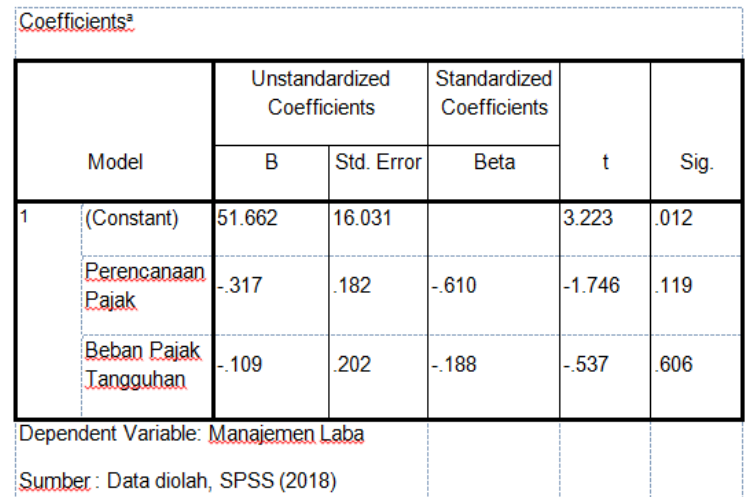

Berdasarkan hasil penelitian yang dilakukan terlihat bahwa variabel perencanaan pajak tidak berpengaruh terhadap variabel manajemen laba. Walaupun pengaruh perecanaan pajak lemah, artinya masih banyak faktor lain yang menentukan terjadinya manajemen laba. Begitupun dengan beban pajak tangguhan tidak berpengaruh terhadap manajemen laba artinya beban pajak tangguhan dapat dijadikan indikator dalam mendeteksi manajemen laba, walaupun pengaruhnya lemah terhadap manajemen laba. Penelitian ini juga membuktikan bahwa memang terjadi manajemen laba dengan tujuan menghindari pelaporan kerugian pada perusahaan-perusahaan yang terdaftar di Bursa Efek Indonesia tahun 2013 2015.

Hasil penelitian ini sejalan dengan hasil penelitian Ni Komang Anggreni (2015), Tiara Timuriana (2016), dan Issan Chairul Imam (2016). Namun hasil ini tidak sejalan dengan hasil penelitian Devi Intan Satyaningrum (2016), Herdawati (2015) dan Esti Mustika Sari (2016).

\section{KESIMPULAN DAN SARAN}

Berdasarkan hasil analisis dan pembahasan, maka kesimpulan penelitian ini sebagai berikut:

1. Perencanaan pajak tidak memiliki pengaruh signifikan terhadap manajemen laba, Oleh karena itu hipotesis yang mengatakan bahwa perencanaan pajak berpengaruh terhadap manajemen laba ditolak.

2. Beban pajak tangguhan tidak memiliki pengaruh signifikan terhadap manajemen laba, artinya hipotesis yang mengatakan beban pajak tangguhan berpengaruh terhadap manajemen laba ditolak.

\section{DAFTAR RUJUKAN}

Ampa, Andi. 2011. Implementasi Tax Planning dalam Upaya Meningkatkan Kinerja Perusahaan 
Lusiana Kanji, Perencanaan Pajak dan Beban Pajak Tangguhan terhadap Manajemen Laba Pada Perusahaan Manufaktur yang Terdaftar di Bursa Efek Indonesia | 27

pada PT Bank sulsel. Makassar: Universitas Hasanuddin.

Chairul, Issan. 2016. Kajian Empiris Beban Pajak Tangguhan dan Kepemilikan Institusional Terhadap Manajemen Laba. Jurnal Infestasi, Vol.12, No.1.

Ghozali, Imam. 2013. Aplikasi Analisis Multivariate dengan Program SPSS. Cetakan keempat. Badan Penerbit Universitas Diponegoro: Semarang.

Godfrey, A. Hodgson, A. Tarca, A. Hamilton, Jane. 2010. Accounting Theory. 7th Edition. Australia: John Wiley \& Sons Australia, Ltd.

Hairu Ningsih. 2009. “Hubungan antara Manajemen Laba, Good Corporate Governance, dan Struktur Pengendalian Intern terhadap Perencanaan Audit”. Skripsi. Jakarta: Fakultas Ekonomi UTIRA-IBEK.

Ikatan Akuntan Indonesia. 2007. Standar Akuntansi Keuangan. Jakarta: Ikatan Akuntan Indonesia.

Lukman, Pungky. 2013. Kemampuan Beban Pajak Tangguhan dalam Memprediksi Ukuran Manajemen Laba. Semarang: Universitas Diponegoro.

Mardiasmo. 2011. Perpajakan Edisi Revisi. Yogyakarta: ANDI

Mulford dan Comiskey. 2010. Manajemen Laba. Jakarta: Indonesia

Nurjannah. 2013. Implementasi Perencanaan Pajak (Tax Planning) untuk Penghematan Jumlah Pajak Penghasilan pada Pt. Semen Bosowa Maros. Makassar: Universitas Hasanuddin.

PSAK No. 46 Pajak Penghasilan. 2010. Exposure Draft Pernyataan Standar Akuntansi Keuangan. Ikatan Akuntansi Indonesia.

Rosdiana, Haula dan Edi Slamet Irianto. 2011. Panduan Lengkap Tata Cara Perpajakan di Indonesia. Jakarta: Visimedia.
Satyaningrum. 2016. Analisis Pengaruh Beban Pajak Tangguhan dan Perencanaan Pajak Terhadap Manajemen Laba. Jurnal Akuntansi dan Keuangan Indonesia.

Suandy, Erly. 2011. Perencanaan Pajak. Jakarta: Salemba Empat.

Sugiyono. 2013. Metode Penelitian Bisnis. Bandung: Alfabeta

Sulistyanto, H. Sri. 2008. Manajemen Laba, Teori dan Model Empiris. Jakarta: Grasindo.

Timuriana, Tiara. 2015. Pengaruh Aset Pajak Tangguhan dan Beban Pajak Tangguhan Terhadap Manajemen Laba. The Accounting Review, Vol.1, No.2.

Undang-undang Perpajakan Tahun 2000. Bandung: Citra Umbara.

Undang-Undang Republik Indonesia Nomor 17 Tahun 2000 Tentang Pajak Penghasilan.

Yuliani. 2013. Pengaruh Penurunan Tarif Pajak Penghasilan Badan Menurut Uu No. 36 Tahun 2008, Insentif Pajak dan Nonpajak terhadap Manajemen Laba pada Perusahaan Manufaktur Di Indonesia. Semarang: Universitas Diponegoro. 